\title{
Prevalence of Reproductive Disorders in Niali and Kantapara Block of Cuttack District, Odisha, India
}

\author{
P.P. Harichandan ${ }^{1 *}$, A.K. Barik ${ }^{1}$, P.C. Mishra ${ }^{1}$, B.K. Patra ${ }^{1}$, B. Jena ${ }^{1}$, \\ R. Patra ${ }^{2}$ and A.K. Kund ${ }^{3}$ \\ ${ }^{1}$ Department of Animal Reproduction, Gynaecology and Obstetrics, ${ }^{2}$ Department of \\ Veterinary Anatomy, ${ }^{3}$ Department of Animal Physiology, CVSc \& AH, OUAT, \\ Bhubaneswar, Odisha-751003, India \\ *Corresponding author
}

\section{Keywords}

Reproductive disorder, Body condition score, parity

Article Info

Accepted:

12 April 2018

Available Online:

10 May 2018

A B S T R A C T

A survey was conducted to study the incidence of infertility in crossbred cows and distribution of repeat breeding crossbred animals in Niali and Kantapara block of Cuttack district, Odisha, India which revealed that, the incidence of reproductive problems were 45.18 per cent in cross bred cows and 25.47 per cent in heifers. Out of the total reproductive disorders, $36.89,51.94$ and 11.17 per cent of cases were recorded as postpartum anoestrus, repeat breeding and miscellaneous disorders, respectively in crossbred cows. In crossbred heifers the incidence of anestrus, repeat breeding, delayed maturity and miscellaneous disorders were recorded to be $38.21,45.53,7.32$ and 8.94 per cent respectively. Incidence of infertility was higher in summer months $(45.29 \%)$ than that in rainy $(25.23 \%)$ or winter $(29.48 \%)$ season. Incidence of repeat breeding in cows included in the study recorded to be highest in second calvers (40.19\%) followed by first (21.50\%) and third calvers $(13.08 \%)$. Incidence of repeat breeding was higher in cows with average daily milk yield of 10-12 litres and above. The cows with 6-8 litres of average daily milk yield recorded to be the lowest $(9.35 \%)$. Incidence rate for repeat breeding in animals was recorded to be highest $(43.56 \%)$ in cows with a body condition score of 1-2. The overall distribution of repeat breeding in animals was found to be 30 and 70 per cent with sub active and functional ovaries. However cows with non-functional ovary did not reveal any repeat breeding problems.

\section{Introduction}

Cattle production has been considered as the main component of agricultural development in most parts of India. Reproductive efficiency is a critical component of a successful dairy operation and acts as an important component of a profitable dairy farm, whereas reproductive inefficiency is one of the most costly problems today. Three major infertility conditions which generally precipitate include delayed sexual maturity, anestrus in heifers, post-partum anestrus in cows and repeat breeding syndrome in both. Anestrus is 
characterized by absence of overt signs of estrus and also affecting the livestock enterprise to a great extent. Repeat breeding has been defined as failure to conceive from three or more regularly spaced services in the absence of detectable abnormalities (Zemjanis, 1963). The incidence of repeat breeders ranges from 4.26 to 42.70 per cent in different managemental herds (Bhosreka, M., 1973). The incidence of anoestrus in cows reported by different workers reveals that, it ranges from 5.01 (Selvaraju et al., 2005) to 65.00 percent (Kutty and Ramachandran, 2003 ) in different states of India. In the state Orissa, as per the different studies undertaken, the incidence of anoestrus in cows ranges from $15.97 \%$ (Das et al., 2004) to $60.82 \%$ (Mohanty et al., 1997). Since these studies were decade old and not area specific, the present study was undertaken in Cuttack district of Orissa for assessing the incidence of infertility in dairy cows and to make strategic planning for dairy improvement in these areas.

\section{Materials and Methods}

The survey was carried out in randomly selected twelve villages of Niali and Kantapara block of Cuttack district to collect the data regarding occurance of various reproductive disorders in bovine herd for a period from July 2014 to December 2015. These blocks were selected because of the higher crossbred cow density in the district. The reproductive status of the dairy cows was assessed by per-rectal examination of individual cows. For this study, a total of 939 crossbred animals (456 cows and 483 heifers) were per rectally examined as per established method of Zemjanis (1970).

\section{Results and Discussion}

The incidence of reproductive disorder and distribution of repeat breeding crossbred animals according to season, parity and milk yield in Niali and Kantapara blocks of Cuttack district is presented in Table 1, 2, 3 and 4 respectively. Our findings are in accordance with the findings of Khan et al., (2016a) who showed that out of 576 dairy cows examined, $33.85 \%(\mathrm{n}=195)$ were found to be affected with one or more reproductive problems.

Out of 456 crossbred cows surveyed, 45.18 per cent were found to have reproductive problems which corroborates with the findings of Haile et al., (2014) who reported 43.3 per cent of dairy cattle having reproductive disorders in Ethiopia. Among 483 heifers surveyed, 25.47 per cent were found to have reproductive disorders. In comparison to the percentage of heifers with reproductive disorders (HRD), higher proportion of crossbred cows were found to have a reproductive problem which is similar with the findings of Das (2016) who recorded the reproductive disorders in cows and heifers as 44.3 and 23.4 per cent respectively. Ras (1999) opined that the higher incidence of reproductive disorders could be due to elevated progesterone levels during estrus and inhibition of estrus behaviour resulting from negative energy balance in high yielding cows. The higher incidence of reproductive disorders in cows as compared to heifers could possibly be due to the repeated exposure of the genital tract of pluriparus cows to environmental risk factors that can impart uterine infection (Haile et al., 2014).

Our findings regarding the incidence of postpartum anoestrus, repeat breeding and other disorders in cows and heifers is similar with the findings of Serur et al., (1982) who reported a higher incidence of repeat breeding $(50.09 \%)$ in cows than heifers $(46.0 \%)$. Thakor and Patel (2013) also studied infertility problems in cows and buffaloes and reported that, incidence in cattle was $32.71,56.07$ and 11.21 per cent for anestrus, repeat breeding and endometritis respectively. Poor nutrition 
and poor management was opined to be the possible reason for smooth ovaries with ill developed genitalia causing reproductive disorders. The incidence of repeat breeding was more in both cows and heifers which is similar with the findings of Khan et al., (2016b).

In contrast high incidence of anoestrus in cows were reported by Singh et al., (2003) and Pandit (2004), which ranged from 49.70 to 67.11 percent in Andhra Pradesh, Punjab and Madhya Pradesh. Mohanty et al., (1997) also reported high incidence of anoestrus cases in Odisha. Low incidence of repeat breeding was also reported by Bhattacharya (2012).

The variation in incidence might be due to plane of nutrition, environmental factors, population size and method of survey adopted. Agarwal et al., (2005) also reported that the incidence of true anestrous in cattle and buffalo varied widely depending upon the level of feeding and management.

Our findings regarding seasonal incidence of several reproductive disorders are similar to the findings of Lim et al., (2015) who reported highest incidence of reproductive disorders in summer $(43.9 \%)$ and lowest in winter (30.9\%). Khair et al., (2013) also reported higher incidence of reproductive disorders in summer months $(1.88 \%)$ followed by rainy $(1.55 \%)$ and winter $(0.48 \%)$. During thermal stress, changes occur in intrauterine environment due to reduced blood flow and increased body temperature (Roman-Ponce et al., 1978). This change was found to be associated with early embryonic mortality and unsuccessful insemination (Rivera and Hanse, 2001). These findings confirm the reported works of many scientists (Das et al., 2003; Mishra, 2011). The "bull factor" is also responsible for reduced fertility of cows because of the poor semen quality of bulls during stressful seasons (Hafez, 1987).
Maximum incidence of repeat breeding was observed between $1^{\text {st }}$ and $3^{\text {rd }}$ parities which corroborates with the findings of Khan et al., (2016b) who reported that parity $1^{\text {st }}-3^{\text {rd }}$ was the most productive phase of female cattle followed by parity $4^{\text {th }}-5^{\text {th }}$. The higher incidence $(21.50 \%)$ in the $1^{\text {st }}$ parity is due to the fact that during this period of age, animals continue to grow whereby the dietary energy intake is partitioned to meet the requirements for maintenance, continuation of growth, lactation and reproduction (Zaman et al., 2014). The occurrence of highest prevalence $(40.19 \%)$ in $2^{\text {nd }}$ parity may be due to lactational stress coupled with metabolic or hormonal imbalance (Kumar et al., 2006). However, relatively lower percentage (13.08 $\%$ and $8.41 \%$ ) of repeat breeders in $3^{\text {rd }}-4^{\text {th }}$ calving might be related to the improved feeding practices adopted by the farmers at the peak lactation. In contrast Asaduzzaman et al., (2016) revealed that significantly lower proportion of cows $(29.1 \%)$ was affected with repeat breeding at $2 \mathrm{nd}-3 \mathrm{rd}$ parity than that of cows at 1 st parity $(33.1 \%)$ and 4 th -9 th $(47.7 \%)(\mathrm{P}<0.05)$.

This may be explained by the fact that first parity cows need more energy supplementation for milk production and its growth, and usually, the farmers supply equal quantity of feed supplement to all parous cows. Khan et al., (2016b) also found that the maximum occurrence of repeat breeding at second lactation may be due to the fact that chances of dystocia are usually high in heifers and mostly the first delivery of animal is manipulated by the farmers or veterinarians. In this way, chances of induction of infections in uterus are high at that time, which can lead to sub-clinical infection of uterus. Similarly, malpractices adopted by the farmers like inserting the tail of animal in the vagina for milk let down may be one of the factors which lead to uterine infections and ultimately repeat breeding. 
Table.1 Incidence of reproductive disorder animals in Niali and Kantapara block of Cuttack

\begin{tabular}{|c|c|c|c|c|c|c|}
\hline particulars & cows & percentage & heifers & percentage & Total & percentage \\
\hline Animals surveyed & 456 & 48.56 & 483 & 51.44 & 939 & 100 \\
\hline Animals with reproductive disorders & 206 & 45.18 & 123 & 25.47 & 329 & 35.04 \\
\hline PPA/Anestrus & 76 & 36.89 & 47 & 38.21 & 123 & 37.39 \\
\hline Repeat breeding & 107 & 51.94 & 56 & 45.53 & 163 & 49.54 \\
\hline Delayed maturity & - & - & 09 & 7.32 & 09 & 2.74 \\
\hline Others & 23 & 11.17 & 11 & 8.94 & 34 & 10.33 \\
\hline
\end{tabular}

Table.2 Seasonal incidence of reproductive disorders

\begin{tabular}{|c|c|c|c|c|c|c|}
\hline \multirow{2}{*}{ Attributes } & \multicolumn{3}{|c|}{ Summer } & (Mar-May) & \multicolumn{3}{|c|}{ Rainy (Jul-Sep) } & \multicolumn{2}{c|}{ Winter (Dec-Feb) } \\
\hline & Heifer & Cow & Heifer & Cow & Heifer & Cow \\
\hline Repeat Breeding & 21 & 58 & 16 & 25 & 19 & 24 \\
\hline Post-partum anestrus & - & 32 & - & 18 & - & 26 \\
\hline Anestrus & 20 & - & 11 & - & 16 & - \\
\hline Delayed maturity & 4 & - & 2 & - & 3 & - \\
\hline Others & 4 & 10 & 4 & 7 & 3 & 6 \\
\hline Average Incidence of the season & & 45.29 & \multicolumn{2}{|c|}{25.23} & \multicolumn{2}{|c|}{29.48} \\
\hline
\end{tabular}

Table.3 Incidence of repeat breeding with respect to parity

\begin{tabular}{|c|c|c|}
\hline Parity & Number of repeat breeders & Parity percentage of repeat breeders \\
\hline $1^{\text {st }}$ calver & 23 & 21.50 \\
\hline $2^{\text {nd }}$ calver & 43 & 40.19 \\
\hline $3^{\text {rd }}$ calver & 14 & 13.08 \\
\hline $4^{\text {th }}$ calver & 9 & 8.41 \\
\hline $5^{\text {th }}$ calver & 6 & 5.61 \\
\hline $6^{\text {th }}$ calver & 4 & 3.74 \\
\hline $7^{\text {th }}$ calver & 4 & 3.74 \\
\hline $8^{\text {th }}$ calver & 2 & 1.87 \\
\hline $9^{\text {th }}$ calver & 1 & 0.93 \\
\hline $10^{\text {th }}$ calver or beyond & 1 & 0.93 \\
\hline Total/ Overall & $\mathbf{1 0 7}$ & $\mathbf{1 0 0}$ \\
\hline
\end{tabular}

Table.4 Incidence of repeat breeding with respect to milk yield

\begin{tabular}{|c|c|c|}
\hline Milk yield (litre) & Number of repeat breeders & Percentage of repeat breeders \\
\hline $10-12$ & 36 & 33.64 \\
\hline $8-10$ & 22 & 20.56 \\
\hline $6-8$ & 10 & 9.35 \\
\hline $4-6$ & 14 & 13.08 \\
\hline $2-4$ & 12 & 11.21 \\
\hline $0-2$ & 13 & 12.15 \\
\hline Total & 107 & 100 \\
\hline
\end{tabular}


After reaching the maximum value in 2 nd lactation, the prevalence of repeat breeding decreased with increase in the parity.

The findings regarding incidence of repeat breeding with respect to milk yield of dairy cows in present study is in accordance with the findings of Asaduzzaman et al., (2016) who found that significantly lower proportion of cows (26.3\%) were affected when they produced 2-5 litres of milk than that of 5-13 litres of milk (52.6\%). The higher incidence of repeat breeding in high producing cows than low yielders might be due to vulnerability of the high producing cows to metabolic and endocrine disturbances which in turn affects conception rates (Zaman et al., 2014).

A contradiction, however, was observed in the present study that the lower producing cows (0-2, 2-4 litres) showed a higher incidence as compared to the higher producing ones (4-6, 6-8 litres). This could be due to the fact that, these cows were not fed properly by the resource-poor farmers because of their poor yield. Hence, theses nutritionally starved animals intensely suffered from lactational stress even with their low yield, leading to reproductive disorders.

The present study revealed that occurrence of repeat breeding animals with respect to body condition score was recorded to be highest $(43.56 \%)$ in $1-2$ BCS and lowest $(24.54 \%)$ in 3-4 BCS which is in accordance with the findings of Asaduzzaman et al., (2016) who stated that the occurrence of repeat breeding was lower in herds with BCS $3(9.0 \%)$ and the occurrence was higher in herds with BCS $1-2(13.9 \%)$. Further among the affected cows, significantly lower proportion of cows (26.3 - 31.4\%) suffered from repeat breeding at BCS $2.5-3.5$ than that of cows at BCS 1-2 $(42.3 \%)$. This is because the cows of herds with low BCS suffer more from negative energy balance resulting in inadequate secretion of reproductive hormones causing fertilization failure or early embryonic death followed by repeat breeding.

In the present experiment, out of 80 crossbred repeat breeding animals examined, it was observed that 70 per cent of experimental animals had functional ovary i.e. those were having either $\mathrm{CL}$ or Regressed $\mathrm{CL}$ or Persistent CL indicating regular cyclical activity. Sub active ovaries are classified as ovaries with soft, rough and round structure indicating gradual follicular activity. These cows though cycling regularly, did not show any heat signs for artificial insemination. Schopper et al., (1993) reported that $41 \%$ of all post-partum ovulations were not accompanied by observed heat symptoms, while in the present experiment, the percentage was much lower $(30 \%)$.

The incidence of various reproductive disorders in bovines in and around Cuttack district can give a brief idea regarding the infertility problems existing in herd and will be helpful in adopting appropriate therapeutic strategy.

\section{References}

Agarwal SK, Singh S K, Rajkumar R (2005). Reproductive disorders and their management in cattle and buffaloes: A review. Indian J. Anim. Sci., 75 (7): 858-873.

Asaduzzaman, KM, Bhuiyan, MMU, Rahman, MM and Bhattacharjee, J. (2016). Prevalence of repeat breeding and its effective treatment in cows at selected areas of Bangladesh. Bangl. J. Vet. Med., 14(2): 183-190.

Bhattacharya HK. 2012. A retrospective study on the prevalence of Bovine gynaecological disorders in rural 
Kashmir, Veterinary Science Research Journal, 3(1 \& 2): 17 - 19.

Bhosreka, M. 1973. Reproductive physiology in Dairy animals. NDRI, Karnal

Das A, Haldar S, Biswas P and Ghosh TK. 2003. Distribution of some major and trace elements in soil, feed, fodder and livestock in red laterite zone of West Bengal, Indian Journal of Animal Nutrition, 20: 136-142.

Das RK, Ray SKH, Mohanty DN, Das S and Jena JC. 2004. Preliminary studies on the incidence of gynaeco-clinical disorders of bovines, Livestock International, 8(3): 6-9.

Das, S. 2016. Factors influencing fertility in dairy cows: Effect of hormonal and nutritional amelioration. PhD thesis submitted to department of livestock production and management, Orissa university of agriculture and technology, Bhubaneswar.

Hafez ESE. 1987. Reproduction in Farm Animals. $5^{\text {th }}$ Edn. Lea and Febiger, Philadelphia, USA.

Haile A, Tsegaye and Tesfaye N. 2014. Assessment of Major Reproductive Disorders of Dairy Cattle in Urban and Per Urban Area of Hosanna, Southern Ethiopia, Animal and Veterinary Sciences, 2(5): 135-141.

Khair A, Alam AA, Rahman MA, Islam MI, Azam A and Chowdhury EH. 2013. Incidence of reproductive and production diseases of cross-bred dairy cattle in Bangladesh, Bangladesh Journal of Veterinary Medicine, 11(1): 31-36.

Khan MH, Manoj K and Pramod S. 2016a. Reproductive disorders in dairy cattle under semi-intensive system of rearing in North Eastern India, Veterinary World, 9(5): 512-518.

Khan, MA, Mushtaq, MH, Khana, MA, Ahmad, N and Nawaz, M. $2016 b$. Incidence of Repeat Breeding in Cattle and Buffaloes of Pakistan. Open access Journal Veterinaria, 4(1): 18-20.

Kumar P and Singhal LK. 2006. Gir: An important milch cattle of Western India, The Indian Cow , 1: 67-68.

Kutty CI and Ramachandran K. 2003. Bovine infertility-A field oriented categorization based on investigation among crossbred cattle in a district of Kerala, Indian Journal of Animal Science, 73(2): 35-37.

Lim HJ, Yoon HB, Im H, Park J, Cho Y, Jeong YS, Ki KS and Im SK. 2015. Survey on the incidence of reproductive disorders in dairy cattle, Journal of Embryo Transfer, 30 (1): 59-64.

Mishra PC. 2011. Investigation into certain hormonal causes of infertility in cattle, PhD Thesis submitted to College of Veterinary Science \& Animal Husbandry, OUAT.

Mohanty LD, Mishra PC, Pradhan RK, Mishra MM., Mitra SK, Mishra SK and Nanda J (1997). Some field observations at infertility clinic in intensive cattle development zone, Cuttack, Orissa. XIV Annual Convention of National Symposium of ISSAR. Bidar. 104.

Pandit RK. 2004. Incidence of different kinds of reproductive disorders in livestock, Indian Journal of Animal Reproduction, 25: $35-36$.

Ras A. 1999. Badania wplywu zaburzen gospodarki energetycznej na procesy rozrodcze krow mlecznych, Rozprawy I monografie. 18. Wyd ART Olsztyn,

Rivera RM and Hansen PJ. 2001. Development of cultured bovine embryos after exposure to high temperatures in the physiological range, Reproduction, 121: 107-115.

Roman-Ponce H, Thatcher WW, Caton D, Barron DH and Wilcox CJ. 1978. Thermal stress effects on uterine blood 
flow in dairy cows, Journal of Animal Science, 46: 175-180.

Schopper D, Schemer R, Weiler U and Claus R. 1993. Einflu $\beta$ der milchleistung auf fruchtbarkeitskriterien der milchkuh post-partum: Auswertung von progesterone profile, Reproduction in Domestic Animals, 28: 225-235.

Selvaraju M, Veerapandian C, Kathiresan D, Chandrahasan C (2005). Incidence of bovine reproductive disorders. Indian Vet. J., 82: 556.

Serur BH, Farrag AA and Gomma A. 1982. Incidence of certain infertility problems among cows and buffaloes in Upper Egypt, Assiut Veterinary Medical Journal, 10: 209-214.

Singh G, Sidhu SS and Verma HK. 2003. Incidence of reproductive disorders of buffaloes in different zones of Punjab state, Journal of Research- Punjab Agriculture University, 40: 79-81.
Thakor D and Patel D. 2013. Incidence of Infertility Problems in Cattle and Buffaloes. Dairy Cattle, Available from http://en.engormix.com/MA-dairy cattle/genetic/articles/incidenceinfertility-problems-cattle-t2757/103p0. htm. Accessed on 15-05-2015.

Zaman MI, Sharma U, Kumar S and Kumar S. 2014. Incidence and factors influencing repeat breeding in crossbred cows, Indian Veterinary Journal, 91 (05): 60-62.

Zemjanis R. 1963. The problem of Repeat Breeding in cattle - Paper presented at New England Veterinary Meeting.

Zemjanis R. 1970. Pregnancy examination. In: Diagnostic and Therapeutic Techniques in Animal Reproduction. 2nd edn, 29: Baltimore: Williams and Wilkins.

\section{How to cite this article:}

Harichandan, P.P., A.K. Barik, P.C. Mishra, B.K. Patra, B. Jena, R. Patra and Kund, A.K. 2018. Prevalence of Reproductive Disorders in Niali and Kantapara Block of Cuttack District, Odisha, India. Int.J.Curr.Microbiol.App.Sci. 7(05): 1683-1689. doi: https://doi.org/10.20546/ijcmas.2018.705.198 